Using Environmental Print to Foster Emergent Literacy

in Children from a Low-SES Community

Michelle M. Neumann

Griffith Institute for Educational Research

Griffith University, QLD 4222, Australia

Please direct correspondence to:

Michelle Neumann: Griffith Institute for Educational Research,

QLD 4222, Australia. Telephone: +61 (0) 756788307

E-mail:m.neumann@griffith.edu.au 


\begin{abstract}
Young children are exposed to environmental print within their communities and this print may be a useful resource to foster emergent literacy skills. This pre-post-test randomised controlled study examined the effects of using environmental print to enhance emergent literacy skills in children aged three to four years $(N=50)$ from a low-SES community in south-east Queensland, Australia. The 8-week (30 min/week) environmental print program provided multisensory strategies for children to interact with environmental print by identifying letters and words, tracing letters with fingers, and writing letters. ANCOVAs were conducted with pre-test scores as covariates. Children in the environmental print group significantly out-performed the control group on print knowledge, sound knowledge, and print awareness skills. The program had moderate to large effects sizes and showed that guiding low-SES preschoolers' interactions with environmental print using multisensory strategies is an effective way to foster emergent literacy skills.

Keywords: environmental print, low-SES, emergent literacy, preschool intervention
\end{abstract}




\section{Using Environmental Print to Foster Emergent Literacy in Children from a Low-SES Community}

Preschoolers from low-SES (socioeconomic status) backgrounds are disadvantaged in many developmental domains (Barnett, 1995; McLoyd, 1998), particularly literacy (Raz \& Bryant, 1990; Snow, Burns, \& Griffin, 1998). Reading and writing are essential skills needed to function in society as reading ability is linked to better social, health, and economic outcomes (Australian Government, 2005; DeWalt, Berkman, Sheridan, Lohr, \& Pignone, 2004). Emergent literacy skills, such as alphabet knowledge, print concepts, phonological awareness, and emergent writing, are important precursors of conventional reading and writing (Sénéchal, Le Fevre, Smith-Chant, \& Colton, 2001; Whitehurst \& Lonigan, 1998). These skills emerge from birth through sociocultural experiences (Goodman, 1986) and lowSES preschoolers tend to lag behind their middle- and upper-SES peers in the development of these skills (Duncan \& Seymour, 2000; Justice, Chow, Capellini, Flanigan, \& Colton, 2003; Korat, 2005; Lynch, 2008).

Foster, Lambert, Abbott-Shim, McCarty, and Franze (2005) reported how low-SES is associated with low emergent literacy ability, with SES (e.g., parental education and occupation) being a significant predictor of child outcomes. Korat (2005) examined this further by comparing emergent literacy skills (print concepts, letter name knowledge, phonemic awareness, emergent writing, environmental print reading) in kindergarten children from a low-SES ( $n=34)$ and a middle SES $(n=36)$ community. Lower SES children performed more poorly on print concepts, phonological awareness, and letter naming than their middle SES peers. Korat (2005) suggested that literacy programs for low-SES preschoolers should focus on promoting alphabet knowledge, print concepts, and early writing and word reading skills. 
Researchers have examined a range of early literacy programs that are aimed to promote emergent literacy skills in low-SES children (Aram, 2006; Aram \& Biron, 2004; Diamond, Gerde, \& Powell, 2008; Justice \& Ezell, 2002; Wasik, Bond, \& Hindman, 2006). Examples include shared story book reading (Whitehurst, Epstein, Angell, Payne, Crone, \& Fischel, 1994; $N=153$ - increased print concepts); print referencing in story books (Justice \& Ezell, 2002; $N=30$ - increased alphabet knowledge, environmental print reading, and word awareness); phonological awareness training (Vadasy \& Sanders, 2010; $N=148-$ increased alphabet knowledge, word reading, and comprehension); joint writing (Aram \& Biron, 2004; $N=71$ - increased alphabet knowledge, phonological awareness, word writing, and orthographic awareness); and enriched play settings (Neuman \& Roskos, 1993; $N=177$ - increased environmental print reading). The overall findings show that storybook reading, joint writing, phonological training, and print-rich play activities support different aspects of emergent literacy development in low-SES children.

However, less research has empirically investigated the direct use of environmental print to foster emergent literacy skills in low-SES children. Environmental print is a ubiquitous print resource that is freely available across communities, with children from different SES backgrounds having similar exposure to environmental print (Dickinson \& Snow, 1987). Examples of environmental print include labels on food products, toys, clothing, and road signs, and this print contains a variety of letters, words, and numerals (Adams, 1990; Horner, 2005; Nutbrown, Hannon, \& Morgan, 2005).

Children are exposed to environmental print from birth, and through sociocultural interactions, they begin to make meaning from and understand the functional nature of these signs and labels (Adams, 1990; Harste, Woodward, \& Burke, 1984; Teale \& Sulzby, 1986). Although pre-reading children decipher environmental print logographically (using logos rather than letter sound analysis skills to decode the print; Frith, 1985; Masonheimer, Drum, 
\& Ehri, 1984), this free resource with its attention-grabbing nature has the potential to support emergent literacy development through adult-guided interactions (Neuman \& Roskos, 1993; Neumann, Hood, Ford, \& Neumann, 2012; Prior \& Gerard, 2004; Vera, 2011; Vukelich, Christie, \& Enz, 2008). Adams (1990) argued that if adults focus young children's attention on letters within environmental print, children will learn to examine individual letters, which in turn would support letter learning.

The benefits of guiding preschoolers to focus on letters and words on environmental print items may transfer from school to home and vice versa (Vera, 2011). Furthermore, repeated interaction with environmental print has the potential to consolidate learning. Numerous vignettes have described environmental print use in the preschool setting (Enz, Prior, \& Gerard, \& Han, 2008; Gerard, 2004; Richgels, Poremba, \& McGee, 1996). For example, Enz et al. (2008) described how a preschool teacher used the highly motivating and visually appealing toy label "Pokemon" to assist children's learning of the letter P. They argued that adults play an important role in guiding young children's interactions with environmental print by drawing their attention to the letters and sounds embedded in environmental print words. Parents may also guide their child's interactions with environmental print (Lass, 1982; McGee \& Richgels, 1989) using strategies such as pointing out letters and numerals, identifying them, and encouraging their child to trace elements of print on signs and product labels with a finger (Neumann, Hood, \& Ford, 2013a; Neumann, Hood, \& Neumann, 2009).

Quasi-experimental studies have examined the effects of direct instructional use of environmental print (Prior, 2003; Vera, 2011; Wepner, 1985). For example, Prior (2003) conducted a 12 -week intervention $(N=107)$ with preschoolers that examined the effect of using environmental print on letter knowledge and environmental print reading. There were two treatment groups and a control group. One treatment group had direct instruction 
with environmental print (e.g., pointing out letters in logos, making logo books) and the other had indirect instruction where children played logo games with minimal teacher instruction. The control group was not systematically or intentionally exposed to environmental print. Prior (2003) found that environmental print reading improved in both treatment groups compared to the control group. However, there was no difference between the three groups on letter name or sound knowledge. As letter knowledge was close to ceiling at pre- and posttest, it was difficult to evaluate the effects of using environmental print on letter knowledge. Prior (2003) also described how lower SES children in the sample appeared to respond more enthusiastically to the environmental print program than higher SES children. Informal feedback from parents suggested that children were noticing letters in signs in the community, suggesting transference of environmental print interactions from school to home.

Vera (2011) examined the use of environmental print to enhance alphabet knowledge and print concepts during a 9-week preschool intervention $(N=56)$ in a high-poverty suburb. The environmental print group used logos familiar to the children (e.g., movie characters) to learn about alphabet letters whereas the control group used children's names, calendars, and alphabet books. Vera (2011) found that alphabet knowledge and print concepts were significantly higher in the environmental print group than the control group. Although Prior's (2003) and Vera's (2011) findings were promising, they were limited to a small number of emergent literacy measures (i.e., print concepts, alphabet knowledge, and environmental print reading) and there was no random assignment to groups. In addition, the programs included storybook reading activities so the unique contribution of environmental print on low-SES children's emergent literacy requires further investigation.

A recent preschool intervention $(N=73)$ with 3- to 4-year-olds used environmental print to guide children's interactions with letters (Neumann, Hood, \& Ford, 2013b). Assessments were conducted at pre-test, post-test, and at eight-week follow up. Children 
were randomly placed in an environmental print group, standard print group, or control group. The two treatment groups received the same program in small instructional groups for 30 minutes each week for eight weeks, except that the standard print group used the same environmental print words in standard black and white manuscript form on cards.

Multisensory activities were incorporated into the program by encouraging preschoolers to point and look at letters (visual), say the letter's name and sound (auditory), move their hand in the sky in the shape of the letter (kinaesthetic), and trace the letter with a finger (tactile). The environmental print group outperformed the control group on letter sound knowledge, letter writing, environmental print reading, print concepts, and print motivation with most of their gains sustained two months later. The environmental print group performed significantly better than the standard print group on print motivation, environmental print reading, and letter writing. These findings support the use of environmental print as an early literacy intervention tool. However, the study was limited because it examined the program's effectiveness only with children from a mid to high SES community.

\section{The present study}

Neumann et al.'s (2013b) research was extended by recruiting preschoolers (aged three to four years old) from a low-SES community and randomly allocating them to an environmental print or control group. As Neumann et al.'s (2013b) study already showed that environmental print is beneficial for fostering emergent literacy when compared to a control group the present study did not aim to provide a further test of the specific effects of environmental print. Instead, the present study aimed to validate the use of an environmental print literacy program in socioeconomically disadvantaged children. The multisensory approach used by Neumann et al. (2013b) was adopted for the present 8-week (30-minute session per week) intervention program. Tactile and kinaesthetic activities such as tracing the outline of letters with fingers has been found to improve visual memory in delayed readers 
(Hulme, 1981) and enhance letter knowledge and letter writing in young children (Zafrana, Nikoltsou, \& Daniilidou, 2000). Children in the present study were pre- and post-tested on emergent literacy measures that have been assessed in previous environmental print interventions (e.g., alphabet knowledge, print concepts, letter writing, environmental print; Neumann et al., 2013b; Prior, 2003; Vera, 2011) and, on the basis of previous findings, these were expected to improve. Phonological awareness was also expected to improve because the initial phoneme of each environmental print word was emphasized during the activities. Numeral identification was assessed as environmental print commonly contains numerals (e.g., nutrition tables, product weights) and children's exposure to them during the activities may, in turn, support identification of this print. It was predicted that children from a socioeconomically disadvantaged community who were provided with multisensory strategies to interact with letters embedded within environmental print would make more emergent literacy gains than children who did not receive the environmental print program.

\section{Method}

\section{Participants}

Fifty preschool-aged children $(M=48.81$ months; $S D=5.30$; range $=38-56$ months $)$ participated in the study (29 boys, 21 girls). The children were recruited from six preschools in a low-SES community of south-east Queensland, Australia. Children with any developmental problems (i.e., speech and language delays, eyesight or vision problems, serious illness or injury) as determined by a parent questionnaire or whose main language spoken was not English were not included. To ensure children were pre-readers, they were screened using 10 high-frequency words selected from Clay's (2005) word list. Three children whose parents provided consent did not participate (one was excluded due to speech and language problems and two withdrew prior to the beginning of the program). A further 
five children left their respective centre during the intervention and were withdrawn from the study, resulting in a final sample size of 50 children.

The SES measure represents the degree of disadvantage in terms of people's access to materials and social resources and their ability to participate in society. The Australian Bureau of Statistics (2011) reports that this community is differentiated from other areas of Australia by a range of demographic characteristics, such as low weekly household incomes, low level of educational achievement and occupational status, high unemployment, and high proportion of families in public rental housing. Furthermore, this community's high socioeconomic disadvantage is evidenced by having a low Socio-Economic Index for Areas (SEIFA) of only 883 compared with 1002 for Australia (Australian Bureau of Statistics, 2011). Suburbs with a SEIFA index less than 1000 are considered disadvantaged. From the Australian Bureau of Statistics (2011) census report, 5\% of adults living in this community have a Bachelor degree which is substantially lower than the national average of $19 \%$. In terms of occupation level, $7 \%$ and $10 \%$ of adults in this community are professionals or managers respectively, compared with the national average of $13 \%$ and $21 \%$ respectively.

In the present study, the majority of parents were married (74\%), 16\% were single and never married, and $10 \%$ divorced or separated. As seen in Table 1, the proportion of mothers and fathers with a Bachelor degree is $6 \%$ and $4 \%$ respectively, with no parents holding a post-graduate degree. No parents were managers and $8 \%$ of mothers and $7 \%$ of fathers held a professional occupation (see Table 1). This highlights that the present participant sample was below the national average on education and occupation factors.

\section{Procedure}

Following approval from the university ethics committee and permission from the managing directors of six preschools in this low-SES community, the study was advertised to parents of 3- and 4-year-olds. Parents who consented completed a questionnaire detailing 
family and child information (e.g., parent education and occupation). Each child was assessed by a trained researcher for approximately 30 minutes on emergent literacy skills (print concepts, upper and lower case letter name and sound knowledge, numeral name knowledge, phoneme awareness, letter writing, and environmental print reading) in the two weeks immediately prior to the intervention program in a quiet room at the child's preschool.

At each preschool, there was one classroom of 3 to 4 year olds, and children were randomly assigned to the environmental print group $(n=23 ; 14$ boys and 9 girls; mean age $=$ 48.66 months, $S D=4.81)$ or control group $(n=27 ; 15$ boys and 12 girls; mean age $=48.93$ months, $S D=5.77$ ). The method was free random assignment (Graziano \& Raulin, 2007) whereby children in each preschool were randomly assigned through the use of a randomnumber generator to either the environmental print intervention group or control group. Children in the environmental print group were then randomly allocated to small instructional groups of 3 to 5 children in each.

An experienced and registered teacher with 5 years of early years teaching experience not connected to any of the participating six preschools conducted the intervention program, which consisted of a 30-minute session per week for 8 weeks. Each intervention session was completed in a quiet room separate to the children's regular classrooms and attendance was recorded. Children's attendance to the 8 -week intervention program was high $(M=7.13$ sessions, $S D=0.92$ ). The control group received their normal classroom play-based activities with their regular teachers that included physical activities (e.g., sand play) and shared story book reading. In the two weeks immediately following the 8-week environmental print program, the environmental print group and control group were post-tested on emergent literacy measures.

Environmental print program. The eight week environmental print program was based on that used by Neumann et al. (2013b). This multisensory program encourages 
children to use their visual, auditory, kinaesthetic, and tactile senses to learn about letters on environmental print items. The duration of each session was 30 minutes, and the preschoolers sat on a comfortable mat and the instructor sat on a low chair near the children. Weeks 1 to 5 used a different cereal box to teach 3 new letters each week (week 1: M, I, O from MILO; week 2: F, T, P from FROOT LOOPS; week 3: C, F, L from CORN FLAKES; week 4: R, E, B from RICE BUBBLES; week 5: N, G, A from NUTRI-GRAIN).

Each week followed a similar procedure of activities but used different environmental print items that contained the focus letters. For example, the week 1 session began with learning the directional terms up, down, around, and across by singing songs (e.g., Hands go up and down) and moving arms and hands in these directions (5 minutes). Children's attention was then focussed on the letters M, I, and O on a MILO cereal box as they looked and pointed at the letter (visual), listened and said its name and sound (auditory), moved their arm in the shape of the letter (kinaesthetic), and traced the letter with their finger (tactile) using directional language (10 minutes). Each child interacted with each letter (M, I, O) three times using this point, say, move, and trace method. A range of other environmental print items (e.g., Mini Oreos, Milk, Weet-Bix, Ice-cream, VEGEMITE, LEGO, STOP, and EXIT signs) containing the focus letters were also provided for children to interact with and identify the letters (e.g., find the letter game) (5 minutes). Following this, children were given their own blank-paged writing book and pencil. The instructor used a magnetic sketch board to model the writing of each focus letter by saying its name and sound and using directional language (e.g., the letter T goes down and across) to guide children's writing of each letter whilst referring to environmental print items (10 minutes).

Weeks 6 to 8 involved revision of the 15 letters (week 6: M, I, O, F, T; week 7: P, C, F, L, R; week 8: E, B, N, G, A) using activities similar to those in weeks 1 to 5. Children sang songs (5 minutes) and participated in games such as finding and tracing letters on 
environmental print items (15 minutes), and their writing of the focus environmental print letters was modelled by the instructor (10 minutes).

\section{Measures}

Letter name and sound knowledge. Twenty-six upper case letters printed on individual cards $(8 \mathrm{~cm} \times 8 \mathrm{~cm})$ in Century Gothic font with a size of 120 points were presented to children in random order, and they were asked "what is the name of this letter?" then "what is the sound of this letter?" (each correct answer scored 1 point). Any acceptable letter sound was scored as correct (Clay, 2005). Similarly, 26 lower case letters were presented in the same way as the upper case letters, and knowledge of lower case letter names and sounds were scored (max. $=26$ for each upper and lower case letter name and sound test). Test-retest reliability was 0.97 for upper case letter name and 0.78 for upper case letter sound, and 0.96 for lower case letter name and 0.82 for lower case letter sound. Test-retest reliability was based on the present participant sample for an 8-week time period and was calculated for all emergent literacy measures.

Numeral name. Numerals 0 to 9 printed on individual cards $(5 \mathrm{~cm} \times 5 \mathrm{~cm})$ in Century Gothic font with a size of 120 points were presented to children in random order and they were asked "what is the name of this numeral?" (Each correct answer scored 1 point; $\max .=10)$. Test-retest reliability was 0.91 .

Letter writing. Children were asked to write 15 letters (M, I, O, T, P, S, C, F, L, R, E, B, N, G, A) dictated by the researcher (e.g., "Can you write the letter M?”).

Conventionally written letters were scored 1 point with repeated letters scored only once (max. = 15). Schickedanz and Casbergue's (2009) descriptions and examples of pseudo and conventionally written letters were used to determine the correctness of letters. Letter writing test-retest reliability was 0.83 . To determine inter-rater reliability of letter writing, $25 \%$ of the participant sample were randomly selected and scored by two trained researchers. The inter- 
rater scores for name and letter writing were highly correlated $(r=1.0$ and $r=0.98$ respectively $p<.01$ ) showing a high degree of reliability.

Initial phoneme awareness. This measure was adapted from the initial phoneme retrieval test by Aram and Levin (2001) and Aram (2010). Ten monosyllabic words (fox, bus, cat, rug, tap, sun, pig, hat, mop, net) were selected from Bowey’s (1994) phonological sensitivity word lists. Children were asked to provide the opening phoneme for each word. For example, the researcher said "What sound does the word tap start with?" Each correct response scored 1 point $(\max .=10)$. Prior to testing, three practice words $($ ball, leg, hop) were provided and corrective feedback and explanation were given. Test-rest reliability was 0.60 .

Print concepts. Ten items from Clay's (2005) Concepts About Print test suitable for pre-readers were selected and administered through the story book "Stones" by Clay (2008). The items consisted of early print concepts such as where to start reading, directionality, and word and letter concepts. Children scored 1 point for each correct response (max. $=10)$. Testretest reliability was 0.62 .

Environmental print reading. Ten environmental print items that were common in the local area (e.g., grocery store products, road signage) were selected (MILO, EXIT, FROOT LOOPS, LEGO, CORNFLAKES, SUBWAY, RICE BUBBLES, STOP, NUTRIGRAIN, VEGEMITE). Each item was presented in random order in full context (e.g., on a cereal box) as the researcher ran her finger underneath the label and asked "What does this say?" Children scored 1 point for each correct response $(\max .=10)$. Test-retest reliability was 0.64 .

Ready to Read Test (Clay, 2005). Children were screened using 10 words selected from Clay's (2005) word reading test (for, look, and, come, will, he, up, here, to, me). As all children scored 0 they were considered pre-readers. 


\section{Results}

Initial analyses were conducted using principal component analysis (PCA) on the nine measures (upper case letter name, lower case letter name, numeral name, letter writing, upper case letter sound, lower case letter sound, initial phoneme awareness, print concepts, and environmental print reading) with orthogonal rotation (varimax) (Field, 2009). The KaiserMeyer-Olkin statistic of .83 verified the sampling adequacy for the analysis, indicating an adequate sample size, and all KMO values for individual items were $>.73$ which is well above the accepted limit of .5 (Field, 2009). Bartlett's test of sphericity, $\chi^{2}(36)=348.50, p<$ .001 , indicated that correlations between items were sufficiently large for PCA. An initial analysis was run to obtain eigenvalues for each component in the data. Two components had eigenvalues over Kaiser's criterion of 1 and explained $68.43 \%$ of the variance. However, further inspection showed a third component with an eigenvalue of .91 and this explained a further $10.09 \%$ of variance, which was similar to the amount explained by the second component (11.31\%). Based on inspection of the scree plot and Jolliffe's criterion of extracting eigenvalues greater than .7, a three-component solution was thus retained for the final analysis. The first factor (and factor loadings) was labelled print knowledge and consisted of numeral name (.88), upper case letter name (.80), lower case letter name (.79), and letter writing (.74). The second factor was labelled sound knowledge and consisted of lower case letter sound (.86), upper case letter sound (.85), and initial phoneme awareness (.67). The third factor was labelled print awareness and consisted of environmental print reading (.84) and print concepts (.68). These emergent literacy factors are similar to those found in previous research (Lonigan, Burgess, \& Anthony, 2000; Sénéchal, LeFervre, SmithChant, \& Colton, 2001).

Upper case and lower case letter name and sound knowledge and letter writing were rescaled so that each of the nine measures had a score out of 10 . Composite scores were 
formed by summing the individual measures aforementioned for each factor (print knowledge, sound knowledge, and print awareness). Table 2 shows the descriptive statistics of the individual measures.

\section{Pre-test Analyses}

There was no relationship between gender and group membership, $\chi^{2}(1, N=50)=$ $0.14, p=.70$. Independent t-tests showed that the environmental print group and control group did not differ significantly on child age, $t(48)=0.18, p=.86$, maternal education, $t$ $(48)=0.67, p=.51$, paternal education, $t(48)=0.08, p=.93$, maternal occupation, $t(48)=$ $0.92, p=.36$, or paternal occupation, $t(48)=0.08, p=.94$, prior to the intervention. Nor were there any significant differences between groups at pre-test on any of the emergent literacy measures of log print knowledge, $t(48)=0.04, p=.64$, log sound knowledge, $t(48)=0.14, p$ $=.85$, and print awareness, $t(48)=10.27, p=.68$.

\section{Intervention Analyses}

Initial analyses were conducted to check the assumptions that underlie the ANCOVA. Inspection of the histograms, box plots and the Shapiro-Wilk test indicated that the assumption of normality was violated for print knowledge and sound knowledge which was positively skewed but not print awareness. A logarithmic transformation was applied to normalise the distributions for print knowledge and sound knowledge. Inspection of the scatterplots indicated that there was adequate linearity of the relationship between the independent variable and its respective covariate. Homogeneity of the regression slopes as assessed by the interaction term of the independent variable and its respective covariate was acceptable. Levene's test for homogeneity of variance was not significant for log print knowledge and log sound knowledge, $p>.05$, and marginally significant for print awareness, $F(1,48)=4.76, p=.034$. However, the $F$ ratio has been shown to be robust to moderate violations of the homogeneity of variance assumption (Lindman, 1974). 
To examine differences between post-test scores in the intervention and control group, univariate ANCOVAs were conducted using pre-test scores as the covariate. The ANCOVAs indicated that children in the environmental print group performed significantly better than the control group on log print knowledge, $F(1,47)=18.92, p<.001, d=.58$, log sound knowledge, $F(1,47)=4.05, p=0.049, d=.54$, and print awareness, $F(1,47)=101.13, p<$ $.001, d=2.76$. These comparisons at pre-test and post-test for the environmental print group and control group for print knowledge, sound knowledge, and print awareness, can be seen in Figure 1, 2, and 3 respectively.

The environmental print program produced the largest effect for print awareness; skills such as the ability to read environmental print words and understand concepts about letters, words, and directionality were significantly improved. The program had medium effects on print knowledge, enhancing knowledge of letter and numeral names and the ability to write letters when provided with the letter name. The smallest effect of the program was for sound knowledge; the intervention children performed only marginally better than the control group. This finding suggests that using environmental print as a literacy learning tool did not promote letter sound and phoneme awareness skills as effectively as print awareness and print knowledge skills.

\section{Discussion}

Ubiquitous and freely available environmental print is potentially a valuable print resource that can be used to support emergent literacy skills in children from disadvantaged backgrounds. The present study extended previous research (Neumann et al., 2013b; Prior, 2003; Vera, 2011) by evaluating the use of an environmental print program to enhance emergent literacy skills in preschoolers from a low-SES community. Children were randomly placed in an environmental print group or control group and were tested on a range of emergent literacy skills. During the 8-week program (one 30-minute session per week) 
children were guided to interact with environmental print letters and words using multisensory strategies such as tracing letters on labels with fingers and writing them. The program showed the most advantage for enhancing print awareness and print knowledge skills, with a smaller effect on sound knowledge skills. The moderate to large effect sizes for print awareness and print knowledge indicate practical relevance for the program for use with low-SES preschoolers and promote an organised approach when guiding children's interactions with letters and words in environmental print.

\section{Effects on Print Awareness}

The environmental print program had the strongest effect on print awareness skills, with children in the environmental print group gaining significantly greater environmental print reading ability and an increased understanding of print concepts such as left-to-right directionality and letter and word concepts than the control group. This outcome supports using environmental print as an early literacy tool for low-SES preschoolers because it strengthened their knowledge about surrounding print. These results were expected and align closely with previous studies (Neumann et al., 2013b; Prior, 2003; Salewski, 1995; Vera, 2011; Wepner, 1985). By demonstrating the preschoolers' ability to retain and recognise words following the intervention, the findings provide evidence that children from a low-SES community responded positively to environmental print.

Logographic reading of environmental print has been viewed by some researchers as having little effect on early reading development as pre-readers attend only to the logos and not the print itself (Ehri \& Roberts, 2006; Masonheimer et al., 1984). However, others view environmental print reading ability as a stepping stone to reading because children are demonstrating their interest in environmental print and an increasing understanding that print is functional and communicates meaning (Adams, 1990; Bowman \& Treiman, 2004; Harste, Burke, \& Woodward, 1981). Furthermore, Lomax and McGee (1987) found a positive 
association between environmental print reading and literacy skills in children aged three to six years. It is reasonable to suggest that guiding children's interactions with letters and words in environmental print could help propel children further along the path from logographic reading towards partial alphabetic reading where children begin to use lettersound analysis skills to decode words. However, this would require the testing of the environmental print program over a longer duration and warrant longitudinal investigation of its benefits for developing conventional reading skills.

\section{Effects on Print knowledge}

It is well established that identification of letters and numerals is one of the strongest predictors of future reading ability (Foulin, 2005; Scanlan \& Vellutino, 1996; Schatschneider, Fletcher, Francis, Carlson, \& Foorman, 2004). Therefore, considerable emphasis is placed upon the development of these skills in the early years and the implementation of effective intervention programs (Britto, Fuligni, \& Brooks-Gunn, 2006; Landesman Ramey \& Ramey, 2006; Piasta, Purpura, \& Wagner, 2010). The development of evidence-based programs is particularly important for supporting alphabet knowledge in children from disadvantaged backgrounds, as their print knowledge is low compared to middle- and high-SES children (Aram, 2006; Dickinson, McCabe, \& Essex, 2006; Justice \& Ezell, 2002; Korat, 2005).

In accord with the findings of Neumann et al. (2013b) and Vera (2011), the current study showed environmental print to be an effective tool to enhance children's upper and lower case letter naming skills, numeral identification skills, and letter writing. The environmental print group showed significantly greater improvements compared to the control group, with a moderate-sized effect. It is possible that the multisensory aspect of the present program, where children pointed to letters embedded in environmental print, said the letter name, moved their hand in the shape of the letter, and traced letters on the large bold print of environmental print labels with their finger contributed to their improvement in print 
knowledge. In addition, guiding children to write the environmental print letters may have also supported their formation and production of letter shapes.

There is strong evidence that joint writing activities, where an adult supports young children's writing (e.g., using magnetic letters, newspaper cuttings, pencils, crayons) provides positive outcomes for letter and word writing (Aram \& Biron, 2004). The current study extended Aram and Biron's (2004) research by showing that writing activities with environmental print can foster letter writing in low-SES preschoolers. The preschoolers in the present study readily engaged in the activities by tracing letters and words on product labels and signs with fingers and forming these letter shapes in the air using directional language (up, down, around, and across). With pencils, children wrote their own letters and words they had selected from their favourite environmental print item (e.g., LEGO, STOP).

Environmental print contains not only letters, but also numerals (e.g., product weights, nutritional tables). Through increasing experiences and interactions with print, children learn to identify and name letters and numerals by gradually differentiating between these symbol systems (Tolchinsky, 2003; Yamagata, 2007). The exposure to numerals on the packaging during the present program appeared to contribute to an improvement in print knowledge in the environmental print group, although the utility of environmental print to support the development of other early numeracy skills, such as counting and quantity, in low-SES preschoolers requires further investigation. Children's interest in the array of print types on the packaging was further observed during the sessions as they were seen selfinitiating the tracing of letters that were not the focus of the program (e.g., $U$ in NUTRIGRAIN). They also traced letters and numerals on their T-shirts and hats while asking about the letter names. These anecdotal observations are supportive of Neumann et al.'s (2013b) finding that print motivation was greater in the environmental print group than the control groups. 


\section{Effects on Sound Knowledge}

There was a marginally significant improvement in the environmental print group over the control group on letter sound knowledge and initial phoneme retrieval. However, the effect size was relatively small and indicates that the environmental print program may be a more effective tool for improving print awareness and print knowledge than improving sound knowledge. Also, the children in the present study were three and four years of age and knew little about letter sounds prior to the program. It is possible that the environmental print program may have a greater impact on sound learning in older preschoolers who are more developmentally ready to learn about sounds. The environmental print program could potentially have a stronger impact on children's sound knowledge if the program sessions were extended for a longer period (e.g., 6 to 12 months) over the preschool year. Implementing the program in this way would allow more scope to focus on sound patterns in environmental print words (e.g., retrieving initial and final phonemes, rhyming, deleting phonemes) which may further support phoneme awareness and letter sound skills.

\section{Limitations}

Although the current study provides promising findings for using environmental print to foster emergent literacy skills in preschoolers, the small sample size of children that participated from one socioeconomically disadvantaged community limits generalizability. A few mothers and fathers indicated they held a bachelor degree and reported a professional occupation which is indicative of higher SES. However, it is possible that these families were residing in this low-SES suburb with their children attending preschools in a socioeconomically disadvantaged area because of other factors such as unemployment or low household income. The collection of a wider range of family demographic information such as employment status and income in future studies would provide a more comprehensive understanding of families' SES and degree of disadvantage. 
Further work is needed using empirical methods to validate the present environmental print program in regional areas (e.g., Aboriginal communities) and language-minority families where an even greater literacy gap occurs. The current program was brief, and greater gains in letter sound skills and phoneme awareness may have occurred if the environmental print program was extended and implemented by the children's regular class teachers. Also, as the present intervention program was presented to children by one instructor it was not possible to determine whether the effects of the program could be replicated with teachers in other settings.

\section{Future Research}

The types of environmental print used in the present program were commonly available in the child's local community and although speculative, potentially extended children's interactions with these letters at home through real-life activities. For example, the instructor informally observed children sharing about the environmental print they had at home, and this provided rich opportunities for discussion. Parents also provided informal feedback saying they were surprised when their child spontaneously began pointing out letters, for example, in signs along the road. This suggests transference of environmental print experiences between preschool and home settings and is consistent with previous reports by Vera (2011) and Prior (2003).

It has been established that providing literacy strategies for parents to support preschoolers' literacy learning at home is beneficial (Lynch, 2008; Weigel, Martin, \& Bennett, 2010). Studies have shown that low-SES parents do reference environmental print words and letters to their children at home (Purcell-Gates, 1996; Lynch, 2008) and Neumann et al. (2013a) has found associations between parent-child environmental print referencing and aspects of emergent literacy. Although the present study has shown the benefits of using environmental print to enhance print awareness and print knowledge within a preschool 
setting with a trained instructor, future research is needed to investigate whether coaching low-SES parents in environmental print referencing strategies can also foster emergent literacy.

Low-SES families tend to have less access to formal print resources at home (e.g., books; Merlo, Bowman, \& Barnett, 2007) and parents who hold lower literacy levels (Lynch, 2008; Neuman, 1996) may feel more competent using easily identified and freely available environmental print to guide their child's letter learning. For example, parents could be provided with simple strategies used in the present program (e.g., pointing to and tracing letters embedded in environmental print). However, parent views on using environmental print to support their child's learning should also be investigated to determine whether they believe environmental print to be a positive literacy learning resource or that other home literacy activities would be more beneficial. As little empirical research exists on parent use of environmental print to support emergent literacy, further work is needed to examine this, especially in the homes of low-SES families who would benefit from low-cost and easy-touse home literacy activities.

Finally, as young children's emergent literacy and language development encompasses the acquisition of a broad range of skills, children should be encouraged to engage in a variety of environmental print and non-environmental print activities that meet the needs of high-risk children (McGee \& Richgels, 2003). For example, the present program focussed on developing code-based knowledge rather than vocabulary or comprehension skills over only a limited intervention time of eight weeks with one instructor. Future research is needed that examines the use of the environmental print program by other teachers in diverse classroom settings. Such research will inform the optimal use of environmental print within a balanced preschool curriculum that provides a range of environmental print, 
shared reading and writing, and phonological awareness activities within the context of literacy-enriched play settings, as highlighted by Justice and Pullen (2003).

\section{Conclusion}

The present study has shown that organised use of environmental print within a preschool setting over an eight week period can foster print awareness, print knowledge, and sound knowledge in children from a socioeconomically disadvantaged community. The environmental print program was beneficial in supporting print-based skills such as letter name knowledge and letter writing, whereby children were guided to use multisensory strategies to identify and interact with individual letters by tracing and forming their shapes. It is recommended that early childhood educators working in disadvantaged communities directly utilise freely available and meaningful environmental print to support early print learning in low-SES children. 


\section{References}

Adams, M. J. (1990). Beginning to read: Thinking and learning about print. Cambridge, MA: MIT Press.

Aram, D. (2006). Early literacy interventions: The relative roles of storybook reading, alphabetic activities and their combination. Reading and Writing, 19, 489-515. doi:10.1007/s11145-006-9005-2

Aram, D. (2010). Writing with young children: A comparison of paternal and maternal guidance. Journal of Research in Reading, 33, 4-19. doi:10.1111/j.14679817.2009.01429.x

Aram D., \& Biron, S. (2004). Joint storybook reading and joint-writing interventions among low SES preschoolers: Differential contributions to early literacy. Early Childhood Research Quarterly, 19, 588-610. doi: 10.1016j.ecresq.2004.10.003

Aram, D., \& Levin, I. (2001). Mother-child joint writing in low SES: Sociocultural factors, maternal mediation, and emergent literacy. Cognitive Development, 16, 831-852. doi:10.1016/S0885-2014(01)00067-3

Australian Bureau of Statistics. (2011). Census of population and housing. Retrieved from http://www.abs.gov.au/census

Australian Government. (2005). National inquiry into the teaching of literacy: Teaching reading, report and recommendations (Publication No. 064277577 X). Canberra, Australian Capital Territory: Government Printing Office, Commonwealth of Australia.

Barnett, W. S. (1995). Long-term effects of early childhood programs on cognitive and school outcomes. The Future of Children, 5, 25-50. doi: 10.2307/1602366

Bowey, J. A. (1994). Phonological sensitivity in novice readers and nonreaders. Journal of Experimental Child Psychology, 58, 134-159. doi: 10.1006/jecp.1994.1029 
Bowman, M., \& Treiman, R. (2004). Stepping stones to reading. Theory into Practice, 43, 295-303. doi: 10.1207/s15430421tip4304_8

Britto, P. R., Fuligni, A. S., \& Brooks-Gunn, J. (2006). Reading ahead: Effective interventions for young children's early literacy development. In S. B. Neumann, \& D. K. Dickinson (Eds.), Handbook of early literacy research (Vol. 2, pp. 311-332). New York, NY: Guildford Press.

Clay, M. M. (2005). An observation survey of early literacy development. Auckland, NZ: Heinemann.

Clay, M. M. (2008). Stones. Rosedale, NZ: Pearson.

Dewalt, D. A., Berkman, N. D., Sheridan, S., Lohr, K. N., \& Pignone, M. P. (2004). Literacy and health outcomes: A systematic review of the literature. Journal of General Internal Medicine, 19, 1228-1239. doi: 10.1111/j.1525-1497.2004.40153.x

Diamond, K. E., Gerde, H. K., \& Powell, D. R. (2008). Development in early literacy skills during the pre-kindergarten year in Head Start: Relations between growth in children's writing and understanding of letters. Early Childhood Research Quarterly, 23, 467-478. doi: 10.1016/j.ecresq.2008.05.002

Dickinson, D. K., \& Snow, C. E. (1987). Interrelationships among prereading and oral language skills in kindergarteners from two social classes. Early Childhood Research Quarterly, 2, 1-25. doi: 10.1016/0885-2006(87)90010-X

Dickinson, D. K., McCabe, A., \& Essex, M. J. (2006). A window of opportunity we must open to all: The case for preschool with high-quality support for language and literacy. In S. B. Neumann, \& D. K. Dickinson (Eds.), Handbook of early literacy research. (Vol. 2, pp. 311-332). New York, NY: Guildford Press.

Duncan, L. G., \& Seymour, P. H. K. (2000). Socio-economic differences in foundation-level literacy. British Journal of Psychology, 91, 145-166. doi: 10.1348/000712600161736 
Enz, B. J. Prior, J., Gerard, M. R., \& Han, M. (2008). Exploring intentional instructional uses of environmental print in preschool and primary grades. In A. DeBruin-Parecki (Ed.), Effective early literacy practice: Here's how, here's why (pp. 15-24). Baltimore, MD: Paul. H. Brookes.

Ehri, L. C., \& Roberts, T. (2006). The roots of learning to read and write: Acquisition of letters and phonemic awareness. In D. K. Dickinson, \& S. B. Neuman (Eds.), Handbook of early literacy research. (Vol. 2, pp. 113-131). New York, NY: Guilford Press.

Field, A. (2009). Discovering statistics using SPSS. London, UK: Sage.

Foster, M. A., Lambert, R., Abbott-Shim, M., McCarty, F., \& Franze, S. (2005). A model of home learning environment and social risk factors in relation to children's emergent literacy and social outcomes. Early Childhood Research Quarterly, 20, 13-36. doi:10.1016/j.ecresq.2005.01.006

Foulin, J. N. (2005). Why is letter-name knowledge such a good predictor of learning to read? Reading and Writing: An Interdisciplinary Journal, 18, 129-155. doi:10.1007/s11145-004-5892-2

Frith, U. (1985). Beneath the surface of developmental dyslexia. In K. Patterson., J. Marshall, \& M. Coltheart (Eds.), Surface dyslexia: Neuropsychological and cognitive studies of phonological reading (pp. 301-330). London, UK: Erlbaum.

Gerard, M. (2004). What's a parent to do?: Phonics and other stuff. Childhood Education, 80, 159-160.

Goodman, Y. M. (1986). Children coming to know literacy. In W. H. Teale, \& E. Sulzby (Eds.), Emergent literacy: Writing and reading (pp. 1-14). Norward, NJ: Ablex.

Graziano, A. M., \& Raulin, M. L. (2007). Research methods a process of inquiry. New York, NY: Pearson. 
Harste, J. C., Burke, C. L., \& Woodward, V. A. (1981). Examining our assumptions: A transactional view of literacy and learning. Research in the Teaching of English, 18, 84-108.

Harste, J. C., Woodward, V. A., \& Burke, C. L. (1984). Language stories and literacy lessons. Portsmouth, NH: Heinemann.

Horner, S. L. (2005). Categories of environmental print: All logos are not created equal. Early Childhood Education Journal, 33, 113-119. doi:10.1007/s10643-005 0029-z

Hulme, C. (1981). The effects of manual tracing on memory in normal and retarded readers: Some implications for multisensory teaching. Psychological Research, 43, 179-191.

Justice, L. M., \& Ezell, H. K. (2002). Use of storybook reading to increase print awareness in at-risk children. American Journal of Speech-Language Pathology, 11, 17-29. doi: $10.1044 / 1058-0360(2002 / 003)$

Justice, L. M., Chow, S., Capellini, C., Flanigan, K., \& Colton, S. (2003). Emergent literacy intervention for vulnerable preschoolers: Relative effects of two approaches. American Journal of Speech Language Pathology, 12, 320-332. doi:10.1044/10580360(2003/078)

Justice, L. M., \& Pullen, P.C. (2003). Promising interventions for promoting emergent literacy skills: Three evidence-based approaches. Topics in Early Childhood Special Education, 23, 99-113. doi:10.1177/02711214030230030101

Korat, O. (2005). Contextual and non-contextual knowledge in emergent literacy development: A comparison between children from low SES and middle SES communities. Early Childhood Research Quarterly, 20, 220-238. doi:10.1016/j.ecresq.2005.04.009 
Landesman Ramey, S., \& Ramey, C. T. (2006). Early educational interventions: Principles of effective and sustained benefits from targeted early education programs. In S. B. Neumann, \& D. K. Dickinson (Eds.), Handbook of early literacy research (Vol. 2, pp. 445-459). New York, NY: Guildford Press.

Lass, B. (1982). Portrait of my son as an early reader. The Reading Teacher, 36, 20-28.

Lindman, H. R. (1974). Analysis of variance in complex experimental designs. San Francisco, CA: W. H. Freeman

Lomax, R. G., \& McGee, L. M. (1987). Young children's concepts about print and reading: Toward a model of word reading acquisition. Reading Research Quarterly, 22, 237256. doi: $10.2307 / 747667$

Lonigan, C. J., Burgess, S. R., \& Anthony, J. L. (2000). Development of emergent literacy and early reading skills in preschool children: evidence from a latent-variable longitudinal study. Developmental Psychology, 36, 596-613. doi:10.1037//00121649.36.5.596

Lynch, J. (2008). Engagement with print: Low-income families and Head Start children. Journal of Early Childhood Literacy, 8, 151-175. doi:10.1177/1468798408091853

Masonheimer, P. E., Drum, P. A., \& Ehri, L. C. (1984). Does environmental print identification lead children into word reading? Journal of Reading Behavior, 16, 257271. doi: $10.1080 / 10862968409547520$

McGee, L. M., \& Richgels, D. J. (1989). "K is Kristen's": Learning the alphabet from a child's perspective. The Reading Teacher, 43, 216-225.

McGee, L. M., \& Richgels, D. J. (2003). Designing early literacy programs: Strategies for at-risk preschool and kindergarten children. New York, NY: Guilford Press.

McLoyd, V. C. (1998). Socioeconomic disadvantage and child development. American Psychologist, 53, 185-204. doi: 10.1037/0003-0066X.53.2.185 
Merlo, L. J., Bowman, M., \& Barnett, D. (2007). Parental nurturance promotes reading acquisition in low socioeconomic status children. Early Education and Development, 18, 51-69. doi:10.1080/10409280701274717

Neuman, S. B. (1996). Children engaging in storybook reading: The influence of access to print resources, opportunity, and parental interaction. Early Childhood Research Quarterly, 11, 495-513. doi: 10.1016/S0885-2006(96)90019-8

Neuman, S. B., \& Roskos, K. (1993). Access to print for children of poverty: Differential effects of adult mediation and literacy-enriched play settings on environmental and functional print tasks. American Educational Research Journal, 30, 95-122. doi:10.3102/00028312030001095

Neumann, M. M., Hood, M., \& Neumann, D. L. (2009). The scaffolding of emergent literacy skills in the home environment: A case study. Early Childhood Education Journal, 36, 313-319. doi: 10.1007/s10643-008-0291-y

Neumann, M. M., Hood, M., Ford, R., \& Neumann, D. L. (2012). The role of environmental print in emergent literacy. Journal of Early Childhood Literacy, 12, 231-258. doi: $10.1177 / 1468798411417080$

Neumann, M. M., Hood, M., \& Ford, R. (2013a). Mother-child referencing of environmental print and its relationship with emergent literacy skills. Early Education and Development, 24, 1175-1193. doi:10.1080/10409289.2013.753567.

Neumann, M. M., Hood, M., \& Ford, R. (2013b). Using environmental print to enhance emergent literacy and print motivation. Reading and Writing: An Interdisciplinary Journal, 26, 771-793. doi 10.1007/s11145-012-9390-7.

Nutbrown, C., Hannon, P., \& Morgan, A. (2005). Early literacy work with families: Policy, practice and research. London, UK: Sage. 
Piasta, S. B., Pupura, D. J., \& Wagner, R. K. (2010). Fostering alphabet knowledge development: A comparison of two instructional approaches. Reading and Writing: An Interdisciplinary Journal, 23, 607-626. doi: 10.1007/s11145-009-9174-X

Prior, J. L. (2003). Real world print in the classroom: Meaningful connections for learning to read. (Unpublished doctoral dissertation). Retrieved from Proquest UMI (No. 3084666).

Prior, J., \& Gerard, M. (2004). Environmental print in the classroom: Meaningful connections for learning to read. Newark, DE: International Reading Association.

Purcell-Gates, V. (1996). Stories, coupons, and the TV guide: Relationships between home literacy experiences and emergent literacy knowledge. Reading Research Quarterly, 31, 406-428. doi: 10.1598/RRQ.31.4.4

Raz, I. S., \& Bryant, P. (1990). Social background, phonological awareness, and children's reading. British Journal of Developmental Psychology, 8, 209-225. doi:10.1111/j.2044-835X.1990.tb00837.x

Richgels, D. J., Poremba, K, J., \& McGee, L. M. (1996). Kindergarteners talk about print: Phonemic awareness in meaningful contexts. The Reading Teacher, 49, 632-642.

Salewski, W. C. (1995). The effect of environmental print reading on the literacy development of kindergarten children. (Unpublished master's dissertation). The University of British Columbia, Vancouver, Canada.

Scanlon, D. M., \& Vellutino, F. R. (1996). Prerequisite skills, early instruction, and success in first-grade reading: Selected results from a longitudinal study. Mental Retardation and Developmental Disabilities Research Reviews, 2, 54-63. doi:10.1002/(SICI)10982779 
Schatschneider, C., Fletcher, J. M., Francis, D. J., Carlson, C. D., \& Foorman, B. R. (2004). Kindergarten prediction of reading skills: A longitudinal comparative analysis. Journal of Educational Psychology, 96, 265-282. doi: 10.1037/0022-0663.96.2.265

Schickedanz, J. A., \& Casbergue, R. M. (2009). Writing in preschool: Learning to orchestrate meaning and marks. Newark, DE: International Reading Association.

Sénéchal, M., Le Fevre, J., Smith-Chant, B. L., \& Colton, K. V. (2001). On refining theoretical models of emergent literacy the role of empirical evidence. Journal of School Psychology, 39, 439-460. doi: 10.1016/S0022-4405(01)00081-4

Snow, C. E., Burns, S., \& Griffin, P. (1998). Preventing reading difficulties in young children. Washington, DC: National Academy Press.

Teale, W. H., \& Sulzby, E. (Eds.) (1986). Emergent literacy: Writing and reading. Norwood, NJ: Ablex.

Tolchinsky, L. (2003). The cradle of culture and what children know about writing and numbers before being taught. Mahwah, NJ: Lawrence Erlbaum.

Vadasy, P. F., \& Sanders, E. A. (2010). Efficacy of supplemental phonics based instruction for low-skilled kindergarteners in the context of language minority status and classroom phonics instruction. Journal of Educational Psychology, 102, 786-803. doi:10.1037/a0019639

Vera, D. (2011). Using popular culture print to increase emergent literacy skills in one highpoverty urban school district. Journal of Early Childhood Literacy, 11, 307-330. doi:10.1177/1468798411409297

Vukelich, C., Christie, J., \& Enz, B. (2008). Helping young children learn language and literacy: Birth through kindergarten. Boston, MA: Pearson. 
Wasik, B., Bond, M., \& Hindman, A. (2006). The effects of a language and literacy intervention on Head Start children and teachers. Journal of Educational Psychology, 98, 63-74. doi: 10.1037/0022-0663.98.1.63

Weigel, D. J., Martin, S. S., \& Bennett, K. K. (2010). Pathways to literacy: Connections between family assets and preschool children's emergent literacy skills. Journal of Early Childhood Research, 8, 5-22. doi: 10.1177/1476718X09345518

Wepner, S. B. (1985). Linking logos with print for beginning reading success. Reading Teacher, 38, 633-639.

Whitehurst, G. J., \& Lonigan, C. J. (1998). Child development and emergent literacy. Child Development, 69, 848-872. doi: 10.1111/j.1467-8624.1998.tb06247.x

Whitehurst, G. J., Epstein, J. N., Angell, A. L., Payne, A. C., Crone, D. A., \& Fischel, J. E. (1994). Outcomes of an emergent literacy intervention in Head Start. Journal of Educational Psychology, 86, 542-555. doi: 10.1037/0022-0663.86.4.542

Yamagata, K. (2007). Differential emergence of representational systems: Drawings, letters and numerals. Cognitive Development, 22, 244-257. doi:10.1016/j.cogdev.2006.10.006

Zafrana, M., Nikoltsou, K., \& Daniilidou, E. (2000). Effective learning of writing and reading at preschool age with a multisensory method: A pilot study. Perceptual and Motor Skills, 91, 435-446. doi:10.2466/PMS.91.6.435-446 
Table 1

Parent Education and Occupation $(N=50)$

\begin{tabular}{|c|c|c|}
\hline Demographic factors & $\begin{array}{l}\text { Percentage } \\
\text { of mothers }\end{array}$ & $\begin{array}{l}\text { Percentage } \\
\text { of fathers }\end{array}$ \\
\hline \multicolumn{3}{|l|}{ Education } \\
\hline Less than $7^{\text {th }}$ grade & 0 & 0 \\
\hline Junior high school $\left(7^{\text {th }}-9^{\text {th }}\right.$ grade $)$ & 0 & 7 \\
\hline Partial high school $\left(10^{\text {th }}-11^{\text {th }}\right.$ grade $)$ & 24 & 27 \\
\hline High school graduate $\left(12^{\text {th }}\right.$ grade $)$ & 33 & 23 \\
\hline Partial college or specialised training (e.g., trade) & 37 & 39 \\
\hline University degree (e.g., Bachelor) & 6 & 4 \\
\hline Post-graduate degree or training & 0 & 0 \\
\hline \multicolumn{3}{|l|}{ Occupation } \\
\hline Labourers & 3 & 20 \\
\hline Elementary clerical, sales, and service workers & 26 & 12 \\
\hline Intermediate production and transport workers & 3 & 10 \\
\hline Intermediate clerical, sales, and office workers & 23 & 2 \\
\hline Advanced clerical and service workers & 6 & 0 \\
\hline Trades persons & 3 & 29 \\
\hline Para professionals & 28 & 20 \\
\hline Professionals & 8 & 7 \\
\hline Managers & 0 & 0 \\
\hline
\end{tabular}


Table 2

Descriptive Statistics: Mean (Standard Deviation, Range)

\begin{tabular}{|c|c|c|c|c|}
\hline \multirow[t]{2}{*}{ Variable } & \multicolumn{2}{|c|}{ Pre-test } & \multicolumn{2}{|c|}{ Post-test } \\
\hline & EP & Control & EP & Control \\
\hline Print concepts ${ }^{\mathrm{a}}$ & $3.74(1.74,0-7)$ & $3.11(1.28,1-6)$ & $4.70(1.99,2-9)$ & $3.22(1.60,1-9)$ \\
\hline Upper case letter name ${ }^{\mathrm{b}}$ & $2.61(3.41,0-12)$ & $3.37(5.41,0-22)$ & $7.22(6.18,0-25)$ & $4.78(6.82,0-25)$ \\
\hline Upper case letter sound ${ }^{\mathrm{b}}$ & $0.43(1.08,0-5)$ & $0.37(1.01,0-5)$ & $1.78(1.78,0-8)$ & $1.33(3.26,0-13)$ \\
\hline Lower case letter name $^{b}$ & $1.57(2.21,0-9)$ & $2.78(4.95,0-20)$ & $4.78(4.59,0-18)$ & $3.70(5.84,0-23)$ \\
\hline Lower case letter sound ${ }^{\mathrm{b}}$ & $0.22(0.67,0-3)$ & $0.19(0.40,0-1)$ & $1.61(1.23,0-6)$ & $1.11(2.83,0-11)$ \\
\hline Numeral name $^{a}$ & $2.70(3.76,0-10)$ & $2.19(3.05,0-10)$ & $3.30(3.74,0-10)$ & $2.85(3.38,0-10)$ \\
\hline Phoneme awareness ${ }^{a}$ & $0.30(1.02,0-4)$ & $0.22(1.16,0-6)$ & $0.87(2.42,0-10)$ & $0.93(2.73,0-10)$ \\
\hline Letter writing ${ }^{c}$ & $0.65(0.94,0-3)$ & $1.59(2.06,0-8)$ & $4.22(2.61,1-12)$ & $2.63(2.88,0-10)$ \\
\hline EP reading ${ }^{a}$ & $1.74(1.45,0-5)$ & $2.11(0.97,1-4)$ & $7.09(1.73,4-10)$ & $1.70(1.35,0-5)$ \\
\hline
\end{tabular}

Note. $\mathrm{EP}=$ Environmental print group; $\mathrm{C}=$ Control group; Pre-test = immediately before intervention;

Post-test $=$ immediately after intervention; Maximum test score: ${ }^{\mathrm{a}}=10 ;{ }^{\mathrm{b}}=26{ }^{\mathrm{c}}=15$ 


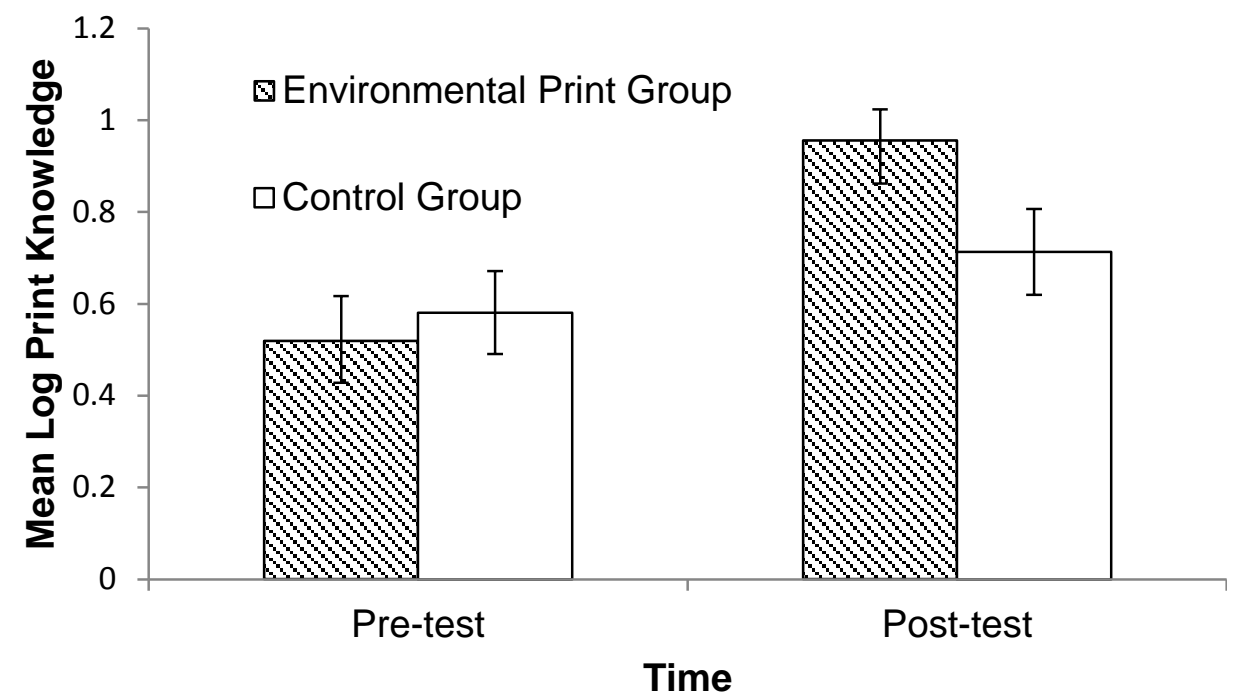

Figure 1. Group means at pre-test and post-test for log print knowledge scores. Error bars represent the standard error of the mean. 


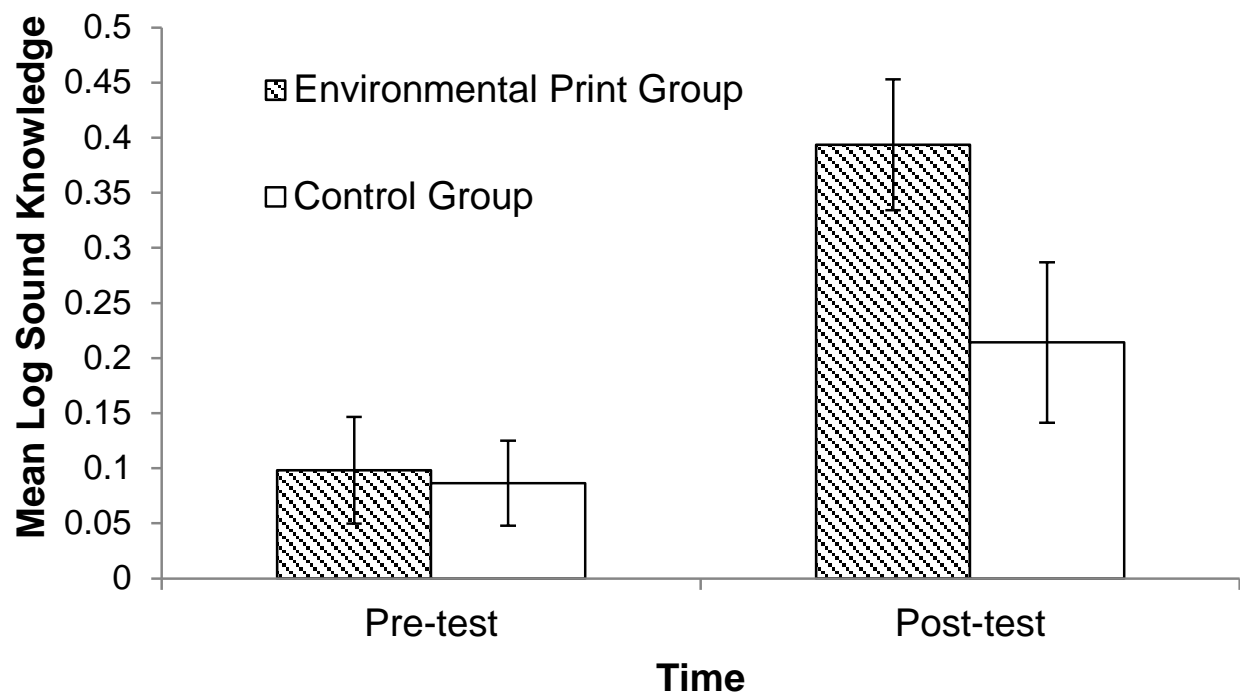

Figure 2. Group means at pre-test and post-test for log sound knowledge scores. Error bars represent the standard error of the mean. 


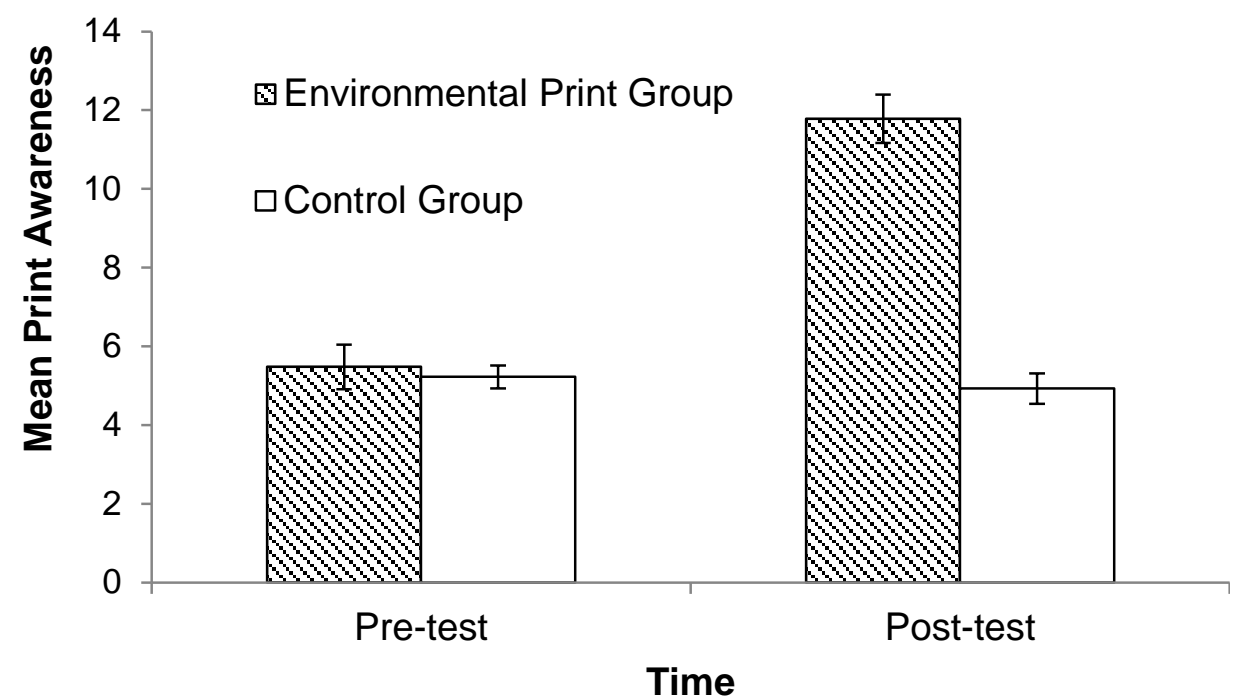

Figure 3. Group means at pre-test and post-test for print awareness scores. Error bars represent the standard error of the mean. 